\title{
Disinfection effect of povidone-iodine in aquaculture water of swamp eel (Monopterus albus)
}

\author{
Xuan Chen ${ }^{1}$, Chongde Lai $^{1}$, Yulan Wang ${ }^{2}$, Lili Wei ${ }^{\text {Corresp.. }}{ }^{3}$, Qiwang Zhong ${ }^{\text {Corresp. } 1}$ \\ ${ }^{1}$ College of Biological Science and Engineering, Jiangxi Agricultural University, Nanchang, China \\ 2 Nanchang Academy of Agricultural Sciences, Nanchang, China \\ 3 College of Animal Science and Technology, Jiangxi Agricultural University, Nanchang, China \\ Corresponding Authors: Lili Wei, Qiwang Zhong \\ Email address: hbliliwei@163.com, zhongqiwang@jxau.edu.cn
}

The swamp eel (Monopterus albus) is an important commercial farmed fish species in China. However, it is susceptible to Aeromonas hydrophila infections, resulting in high mortality and considerable economic loss. Povidone-iodine (PVP-I) is a widely used chemical disinfectant in aquaculture, which can decrease the occurrence of diseases and improve the survival. However, environmental organic matter could affect the bactericidal effectiveness of PVP-I, and the efficacy of PVP-I in aquaculture water is still unknown. In this paper, disinfection assays were conducted to evaluate the effectiveness of PVP-I against the $A$. hydrophila in different types of water. We found that the effective germicidal concentration of PVP-I in outdoor aquaculture water was 25 ppm for 12 hours. In indoor aquaculture water with $10^{5} \mathrm{CFU} / \mathrm{mL}$ bacteria, $10 \mathrm{ppm}$ and $20 \mathrm{ppm}$ of PVP-I could kill $99 \%$ and $100 \%$ of the bacteria, respectively. The minimal germicidal concentration of PVP-I in Luria-Bertani broth was 4000 ppm, respectively. Available iodine content assay in LB solutions confirmed that the organic substance had negative impact on the effectiveness of PVP-I, which was consistent with the different efficacy of PVP-I in different water samples. Acute toxicity tests showed that the $24 \mathrm{~h}-\mathrm{LC}_{50}$ of PVP-I to swamp eel was $173.82 \mathrm{ppm}$, which was much lower than the germicidal concentrations in outdoor and indoor aquaculture water, indicating its safety and effectivity to control the A. hydrophila. The results indicated PVP-I can be helpful for preventing the transmission of $A$. hydrophila in swamp eel aquaculture. 
1 Disinfection effect of povidone-iodine in aquaculture water of swamp eel

\section{(Monopterus albus)}

4 Xuan Chen ${ }^{\mathrm{a} \#}$, Chongde Lai ${ }^{\mathrm{a} \#}$, Yulan Wang ${ }^{\mathrm{b}}$, Lili Weic*${ }^{*}$, Qiwang Zhonga*

a College of Biological Science and Engineering, Jiangxi Agricultural University, 330045,

7 Nanchang, China

${ }^{b}$ Nanchang Academy of Agricultural Sciences, 330038, Nanchang, China

c College of Animal Science and Technology, Jiangxi Agricultural University, 330045, Nanchang,

\section{China}

12 \# These authors contributed equally to the study

$14 *$ Corresponding author 1: Qiwang Zhong

Tel\& Fax: +86-791-83813459

16 Postal address: College of Biological Science and Engineering, Jiangxi Agricultural University,

17 No. 1101 Zhimin Road, Nanchang 330045, P.R. China.

E-mail address: zhongqiwang@jxau.edu.cn

* Corresponding author 2: Lili Wei 
Tel\& Fax: +86-791-83853503

Postal address: College of Animal Science and Technology, Jiangxi Agricultural University, No. 1101 Zhimin Road, Nanchang 330045, P.R. China.

E-mail address: hbliliwei@163.com

\section{Abstract}

The swamp eel (Monopterus albus) is an important commercial farmed fish species in China. However, it is susceptible to Aeromonas hydrophila infections, resulting in high mortality and considerable economic loss. Povidone-iodine (PVP-I) is a widely used chemical disinfectant in aquaculture, which can decrease the occurrence of diseases and improve the survival. However, environmental organic matter could affect the bactericidal effectiveness of PVP-I, and the efficacy of PVP-I in aquaculture water is still unknown. In this paper, disinfection assays were conducted to evaluate the effectiveness of PVP-I against the A. hydrophila in different types of water. We found that the effective germicidal concentration of PVP-I in outdoor aquaculture water (outdoor net cage water) was $25 \mathrm{ppm}$ for 12 hours. In indoor aquaculture water (dechlorinated tap water) with $10^{5} \mathrm{CFU} / \mathrm{mL}$ bacteria, $10 \mathrm{ppm}$ and $20 \mathrm{ppm}$ of PVP-I could kill $99 \%$ and $100 \%$ of the bacteria, respectively. The minimal germicidal concentration of PVP-I in Luria-Bertani broth was 4000 ppm. Available iodine content assay in LB solutions confirmed that the organic substance had negative impact on the effectiveness of PVP-I, which was consistent with the different efficacy of PVP-I in different water samples. Acute toxicity tests 
45 showed that the $24 \mathrm{~h}-\mathrm{LC}_{50}$ of PVP-I to swamp eel was $173.82 \mathrm{ppm}$, which was much lower than

46 the germicidal concentrations in outdoor and indoor aquaculture water, indicating its safety and

47 effectivity to control the $A$. hydrophila. The results indicated PVP-I can be helpful for preventing

48 the transmission of $A$. hydrophila in swamp eel aquaculture.

\section{Introduction}

The swamp eel (Monopterus albus), belongs to Order Synbranchiformes, Family Synbranchidae, and is widely distributed in southern China, Japan, India and other Southeast Asian countries (FishBase, http://fishbase.org/). Due to its great growth performance and rich nutrient content, swamp eel has become a commercially important farmed species in China. However, the intensive and stressful rearing conditions make farmed swamp eels highly susceptible to bacterial pathogens, such as Aeromonas hydrophila, which is the main pathogen causing hemorrhagic septicemia and result in high mortality and considerable economic losses (Hossain et al., 2014; Nielsen et al., 2001). The clinical signs of infection include red and swollen anus, visceral congestion, skin erythema and gill hemorrhage (Jagoda et al., 2014). 
The hemorrhagic septicemia severely restricts the development prospects of the swamp eel farming industry. To prevent the spread of $A$. hydrophila and outbreak of the diseases in aquaculture, the direct and effective method is to reduce the amount of pathogenic bacteria in the aquaculture water. Povidone-iodine (PVP-I) is an important chemical disinfection widely used to disinfect pathogenic organisms and equipments in aquaculture (Scarfe, Lee \& O'Bryen, 2006). It has been reported as a broad-spectrum microbicide with potency to inactivate bacteria, fungi, protozoans, several viruses and some spores (Wutzler et al., 2000). Moreover, PVP-I was determined to be an animal drug of low regulatory priority by the Food and Drug Administration, and suggested to act as an egg surface disinfectant due to the lower irritation and toxicity to tissues (USFDA, 2010). However, many environmental factors can affect the efficacy of PVP-I, such as temperature, $\mathrm{pH}$, organic matter, etc. (Amend, 1974). The presence of organic matter can result in a significant decrease in the bactericidal effectiveness of PVP-I (Rodriguez Ferri et al., 2010). By far, most disinfection research has been carried out in sterile water (Chang et al., 2015), and only very few reports mention use of aquaculture water for testing (Hershberger, Pacheco \& Gregg, 2008).

Swamp eel aquaculture includes outdoor cage culture and indoor tank culture. The former is mainly used for large-scale commercial swamp eel production, and the latter is commonly used in laboratory research. Outdoor aquaculture ponds are complex environments containing large amounts of organic matter and suspended solids (Lin, 2002). However, indoor tank culture mainly uses dechlorinated tap water with water changes every day, so the content of organic matter of indoor culture water is very low. Different contents of organic matter may cause differences in disinfection efficiency of PVP-I (Yoneyama et al., 2006). Accordingly, it is necessary to test whether the organic matter in the aquaculture water is able to cause significant negative effect on disinfection.

The aim of this study was to investigate the germicidal effect of PVP-I on A. hydrophila in three different solutions and attempt to determine the effective disinfection concentrations to control the transmission of $A$. hydrophila. 


\section{Metrials and methods}

96

\section{Bacterial strain}

Six isolates of $A$. hydrophila used in this study (Ah 1-6) were isolated from sick M. albus by our laboratory and stored at $-80{ }^{\circ} \mathrm{C}$ until used. Before disinfection assays, all isolates were subcultured at $25{ }^{\circ} \mathrm{C}$ overnight on solid-phase Luria-Bertani (LB) agar (10 g/L tryptone, $5 \mathrm{~g} / \mathrm{L}$ yeast extract, $10 \mathrm{~g} / \mathrm{L}$ sodium chloride and $15 \mathrm{~g} / \mathrm{L}$ agar powder).

\section{Water sample preparation}

Three different water samples were prepared in this study: outdoor net cage water, dechlorinated tap water and LB broth. These three types of water samples represented outdoor aquaculture waters, indoor aquaculture waters and eutrophic waters, respectively. Outdoor aquaculture waters were sampled from four different net cages of a swamp eel farm, and some of the swamp eel in one cage had typical clinical signs of hemorrhagic septicemia. Tap water samples were filtered through $0.22 \mu \mathrm{m}$ membrane to remove impurities and microbes and autoclaved at $121^{\circ} \mathrm{C}$ for $15 \mathrm{~min}$. LB broth was prepared with deionized distilled water.

\section{Germicidal test}

PVP-I solutions were prepared with different water samples immediately prior to use. For outdoor aquaculture water, $1 \mathrm{~mL}$ of each net cage samples were treated with 5 to $100 \mathrm{ppm}$ PVP-I (final concentration) at $25^{\circ} \mathrm{C}$ in the dark for different durations $(0,2,4,8$ and 12 hours).

For indoor aquaculture water (tap water) and LB solution, A. hydrophila strains were used to evaluate the disinfection effect of PVP-I. Briefly, for indoor aquaculture water, six A. hydrophila isolates (Ah 1-6) were incubated in LB liquid media overnight at $25^{\circ} \mathrm{C}$, respectively. Then $5 \mathrm{~mL}$ of each culture broth was centrifuged at $12000 \mathrm{rpm}$ for 5 minute at $25{ }^{\circ} \mathrm{C}$. The bacterial pellet was washed with tap water three times and then resuspended and diluted to different 
concentration $\left(10^{3}-10^{5} \mathrm{CFU} / \mathrm{mL}\right)$. Disinfection treatments were performed by mixing $900 \mu \mathrm{L}$ of diluted bacteria solutions and $100 \mu \mathrm{L}$ PVP-I solution to a $1 \mathrm{~mL}$ volume containing $10^{3}-10^{5}$ CFU/mL bacteria and 1.25-20 ppm of PVP-I (final concentration). For LB liquid media, only $A$. hydrophila Ah1 isolate (isolated from skin) was used, and the disinfection treatments were performed like those for the indoor aquaculture water except that the tap water was replaced by LB liquid media.

For all above disinfection trials, treatment tubes were incubated at $25^{\circ} \mathrm{C}$ in the dark with gentle mixing. At each nominal exposure time $(0,2,4,8$ and 12 hours), a $160 \mu \mathrm{L}$ aliquot was transferred to a sterile $1.5 \mathrm{~mL}$ microcentrifuge tube, and the equal volume of sodium thiosulfate $(0.004 \mathrm{~mol} / \mathrm{L})$ was added to neutralize the PVP-I immediately. After neutralization, the mixed solution was tenfold serially diluted, and then $100 \mu \mathrm{L}$ of each diluted solution was plated onto LB agar plates in triplicate using sterile beads (Sanders, 2012). Plates were incubated at $25{ }^{\circ} \mathrm{C}$ for 24 hours and colonies were counted. Every experiment was repeated three times.

\section{Effect of organic matter on available iodine}

LB liquid media was 10-fold serially diluted with $\mathrm{ddH}_{2} \mathrm{O}$. Then the $2000 \mathrm{ppm}$ of PVP-I solutions were prepared with serially diluted LB solutions. $1 \mathrm{~mL}$ of PVP-I solution was mixed with $2 \mathrm{~mL}$ of $0.1 \%$ soluble starch solution, and the absorption was measured at $585 \mathrm{~nm}$ immediately. The undiluted LB broth and $\mathrm{ddH}_{2} \mathrm{O}$ were used as controls. The experiment was repeated three times.

\section{Median lethal concentration $\left(\mathbf{L C}_{50}\right)$}

Healthy swamp eel (11-15 g) were obtained from a commercial farm and acclimated in dechlorinated tap water at $25 \pm 1{ }^{\circ} \mathrm{C}$ in $10 \mathrm{~L}$ aquarium tanks for 2 weeks until use. Daily, eels were fed and the tank water replaced with fresh water. The fishes were starved for 24 hours prior to and during the test to reduce the contaminations by fecal and excess food. Five concentrations of PVP-I were chosen for testing purposes (100, 150, 175, 200 and $250 \mathrm{ppm})$ and a group without 
143

144

145

146

147

148

149

150

151

152

153

154

155

156

157

158

159

160

161

162

163

164

165

166

167

PVP-I was used as the control. The duration of exposure was 24 hours. For each concentration and control, three replications were conducted and each replication contained ten swamp eel. Fish were observed every four hours and the dead fish was immediately removed from the test tanks. The $\mathrm{LC}_{50}$ value was calculated using the Probit analysis (Lin, 2002; Lu et al., 2017). After the $\mathrm{LC}_{50}$ test, the surviving individuals were replaced in dechlorinated tap water without PVP-I, fed and the tank water replaced with fresh water daily. The status and survival of the eels were monitored for at least one month. All animal procedures were conducted according to the guidelines for the care and use of experimental animals established by the Ministry of Agriculture of China (No. SCXK YU2005-0001). Animal Care and Use Committee (ACUC) in Jiangxi Agricultural University specially approved this study.

\section{Statistical analysis}

SPSS17.0 was used for data analysis. Significance was evaluated by one-way analysis of variance (ANOVA) using LSD test. A value of $\mathrm{P}<0.05$ was considered to indicate a significant difference. Probit analysis was used to calculate the Median lethal dose.

\section{Results}

\section{The effect of PVP-I in outdoor aquaculture water}

Four outdoor net cage water samples were marked as WA, WB, WC and WD. pH value of these cage water samples were 7.12, 7.25, 7.08 and 7.32, respectively. The water sample WD was taken from a cage in which hemorrhagic septicemia was discovered. According to plate count, the initial cultivable bacterial concentration of these samples were $(0.70 \pm 0.07) \times 10^{3}$ $\mathrm{CFU} / \mathrm{mL},(1.59 \pm 0.23) \times 10^{3} \mathrm{CFU} / \mathrm{mL},(0.38 \pm 0.04) \times 10^{3} \mathrm{CFU} / \mathrm{mL}$ and $(3.96 \pm 0.22) \times 10^{3} \mathrm{CFU} / \mathrm{mL}$, respectively. The germicidal test showed that low concentrations of PVP-I, such as 5 ppm and 10 ppm, could not provide effective disinfection (Fig. 1). When treated with these two concentrations of PVP-I, the average survival decreased in early period, then increased and 
168

169

170

171

172

173

finally up to about 1.5-2.5 fold and 0.8-1.5 fold of initial bacteria amount, respectively. Increasing the PVP-I concentration to $25 \mathrm{ppm}$ significantly improved the bactericidal effects resulting in $98.08 \pm 0.17 \%, 98.74 \pm 0.13 \%, 96.49 \pm 0.03 \%$ and $99.66 \pm 0.03 \%$ mortality in four outdoor water samples for 12 hours, respectively (Fig. 1). However, higher PVP-I concentrations (50-100 ppm) did not significantly increase the sterilization rate $(\mathrm{P}>0.05)$, although $80 \mathrm{ppm}$ and $100 \mathrm{ppm}$ could kill all bacteria in WA and WD samples.

\section{The effect of PVP-I in indoor aquaculture water}

In small-scale indoor farming, the dechlorinated tap water is often used as aquaculture water. The results showed that the effects of PVP-I on six A. hydrophila isolates was similar in tap water, and with the increase of bacterial content, the concentration of PVP-I for complete sterilization increased accordingly. In tap water with $10^{3} \mathrm{CFU} / \mathrm{mL}$ bacteria (Fig. 2A), $1.25 \mathrm{ppm}$ of PVP-I (final concentration) could reduce bacterial counts within 12 hours, but did not completely eliminate the A. hydrophila. Increasing the concentration of PVP-I to $2.5 \mathrm{ppm}$, all bacteria were killed within 4 hours. When the bacterial content was $10^{4} \mathrm{CFU} / \mathrm{mL}$ (Fig. 2B), 10 ppm of PVP-I was required to achieve complete disinfection within 2 hours, and lower concentrations (2.5 ppm and $5 \mathrm{ppm}$ ) could not kill all bacteria. When the bacterial content was $10^{5} \mathrm{CFU} / \mathrm{mL}$ (Fig. 2C), although $10 \mathrm{ppm}$ of PVP-I could kill more than $99 \%$ of the bacteria, to achieve $100 \%$ of sterilization $20 \mathrm{ppm}$ of PVP-I was required. When treated with lower concentrations, the amount of culturable bacteria gradually declined to the lowest in 8 hours, and then increased to different levels.

\section{The effect of PVP-I in LB liquid media}

LB liquid media was used as eutrophic controls. In LB liquid media, neither 500 ppm nor $1000 \mathrm{ppm}$ of PVP-I could inhibit the proliferation of $A$. hydrophila at all bacterial concentrations. For example, in LB solution with $10^{3}, 10^{4}$ and $10^{5} \mathrm{CFU} / \mathrm{mL}$ bacteria (Fig. 3), after 12 hours of incubation with 500 ppm of PVP-I, the number of bacteria increased to 1800, 6050 and 20000 times to the initial number of bacteria, respectively. Increasing the PVP-I concentration to 2000 
194

195

196

197

198

199

200

201

202

203

204

205

206

207

208

209

210

211

212

213

214

215

216

217

ppm only controlled bacteria at the lowest bacteria concentration $\left(10^{3} \mathrm{CFU} / \mathrm{mL}\right.$ of LB medium; Fig. 3A). To achieve complete disinfection, $4000 \mathrm{ppm}$ were required and in this concentration all A. hydrophila could be killed within 2 hours.

\section{Available iodine measurement}

LB medium contained a large amount of organic matter, so it was used to evaluate the effect of organic matter on the available iodine content in this study. The results showed that the concentration of organic matter could significantly affect the available iodine content, and the higher LB concentrations lead to the lower available iodine contents (Fig. 4). In 2 g/L PVP-I solutions, when the concentration of LB was less than $1 \%$, the content of available iodine was equivalent with that in $\mathrm{ddH}_{2} \mathrm{O}$. With the increase of $\mathrm{LB}$ concentration, the available iodine content decreased rapidly, and when the LB concentration was $20 \%$, the effective iodine content almost reduced to zero.

\section{$\mathbf{L C}_{50}$ test}

Median lethal dose of PVP-I was calculated using the Probit analysis (Table S1). According to the equation: Probit $(p)=-5.214+0.03 \times \lg ($ dose $)\left(\chi^{2}=6.343\right)$, the $24 \mathrm{~h}-\mathrm{LC}_{50}$ of PVP-I to swamp eel was $173.82 \mathrm{ppm}$. The individuals that survived the $\mathrm{LC}_{50}$ test did not die within the month following exposure.

\section{Discussion}

Disease is a main threat in aquaculture production and disinfection of water bodies has been used as an important measure to prevent waterborne pathogen transmission in aquaculture (Scarfe, Lee \& O'Bryen, 2006). The present disinfection tests were mainly carried out in sterile water (Hershberger, Pacheco \& Gregg, 2008; Mainous, Smith \& Kuhn, 2010), while very few in aquaculture water. However, there is a great differences between sterile water and aquaculture 
water, and the results obtained in sterile water are not suitable for aquaculture water. The aim of this study was to evaluate the effective concentration of PVP-I against A. hydrophila in outdoor aquaculture water and indoor aquaculture water.

Our study showed that PVP-I was effective to prevent $A$. hydrophila proliferation in outdoor and indoor aquaculture water and there were water-specific differences in susceptibility. The effective germicidal concentration of PVP-I in outdoor aquaculture water, indoor aquaculture water (tap water) and eutrophic water (LB broth) were $25 \mathrm{ppm}, 10 \mathrm{ppm}$ and $4000 \mathrm{ppm}$, respectively. These water-specific differences in bactericidal effect might be mainly caused by organic matter. It had been proved by serially diluted LB solution, in which the higher ratio of organic matter (LB medium) lead to the lower concentration of available iodine, and 20\% LB was sufficient to neutralize all the free iodine in $2000 \mathrm{ppm}$ PVP-I solutions. This result was also supported by many reports which indicated that the efficacy of PVP-I declined when organic matter (e.g. blood, fish mucus, amino acids, or simple aromatic compounds) was present (Truesdale \& Luther, 1995; Yoneyama et al., 2006). Similar results also had been observed in seawater that the content of molecular iodine reduced within hours when added to seawater (Truesdale, Luther \& Canosa-Masb, 1995). Considering the differences in different aquaculture water, it was necessary to determine the effective disinfectant concentration before use. It should be also noted that, in addition to the effects of a small amount of organic matter in tap water, the inorganic matter, such as the hardness of the water, had been proved to affect the available iodine content by influencing $\mathrm{pH}$ (Amend, 1974).

Disinfection can be used not only as a preventive measure in ponds or for equipments, but also as a remedial measure after the outbreak of the disease. The majority of commercially available disinfectants are very effective when used at high concentrations within short contact time. However, for fish, prolonged exposure to high concentrations of disinfectants might be dangerous (Bergmann, Monro \& Kempter, 2017). Especially for extensive outdoor aquaculture, it is impossible to change the water after disinfection. Therefore, it was necessary to determine the toxicity of disinfectants to fish (LeValley, 1982). In this study, the $24 \mathrm{~h}-\mathrm{LC}_{50}$ for M. albus was 
245

246

247

248

249

250

251

252

253

254

255

256

257

258

259

260

261

262

263

264

265

266

267

268

269

270

271

$173.82 \mathrm{ppm}$, which was much higher than the effective germicidal concentration in aquaculture water, suggesting that PVP-I could be used safely as a disinfectant for the culture of M. albus. On the other hand, the commercial standard procedure for PVP-I is to pour directly into the water with the final concentration of $0.075-0.093 \mathrm{ppm}$ for prevention and $0.093-0.125 \mathrm{ppm}$ for treatment (Wang et al., 2015). Our data showed that these recommended concentrations were far less than the effective concentrations and would not have any germicidal effect on $A$. hydrophila.

Compared with higher PVP-I concentration, the lower PVP-I concentrations reduced the toxicity to M. albus, but reduced the bactericidal effect. For example, in outdoor aquaculture water, indoor aquaculture water (tap water) and LB medium, when treated with non-lethal concentration, the number of cultivable bacteria decreased first, then increased during 12 hours. Similar phenomenon was also reported in seawater when treated with some disinfectants (sodium hypochlorite, bleaching powder, formalin) for 12 hours (Wang et al., 2015). The increase of bacteria in later period might be due to the decrease of available iodine content and the proliferation of surviving bacteria. On the one hand, the content of available iodine decreased significantly with the passage of time (Chang et al., 2015); on the other hand, the organic matter in the solution would neutralize free iodine (Takeda et al., 2016). Meanwhile, the organic matter in water samples could supply nutrients for the proliferation of the surviving culturable bacteria. Our results supported this hypothesis; the earliest rise and largest increase of the number of $A$. hydrophila happened in LB broth which contains the most abundant organic matter, followed by outdoor aquaculture water and tap water. Moreover, Kersters et al (1996) reported that $A$. hydrophila was able to grow and proliferation in nutrient-poor filtered and autoclaved tap water, which made it hard to control the proliferation of $A$. hydrophila effectively.

It should be noted that we did not consider the biofilm formation and viable but non-culturable (VBNC) state of $A$. hydrophila. It was reported that the biofilms of $A$. hydrophila was more resistant to disinfectants than planktonic cells (Jahid \& Ha, 2014). Although there was no work about the relationship between the VBNC of $A$. hydrophila and disinfection, it has been demonstrated that stressed and starved A. hydrophila could enter a VBNC state (Pianetti et al., 
272 2008; Rahman, Suzuki \& Kawai, 2001). Disinfectants, such as hypochlorous acid, similarly have 273 induced Escherichia coli and Salmonella typhimurium into the VBNC state (Oliver, Dagher \& 274 Linden, 2005). In this study, when PVP-I concentrations were lower than the effective 275 sterilization concentration, the bacteria might not be completely killed and some of them went 276 into the VBNC state. So the early decline in the number of bacteria might be caused by death 277 cells and VBNC state cells together. As for the subsequent increase in the number of bacteria in 278 outdoor aquaculture water, tap water and LB medium, whether it was associated with the 279 resuscitation and growth of some mildly injured VBNC cells, further study was needed. But, 280 there was some evidence that VBNC bacteria could resuscitate and proliferate under certain conditions (Dukan, Levi \& Touati, 1997). Moreover, the use of disinfectant might result in the development of resistant strains. Nuñez reported the resistant gram-negative rods strains for chlorhexidine, such as $A$. hydrophila, Shigella flexneri (Nuñez \& Moretto, 2007). In addition, resistant Staphylococcus sp. for PVPI were also isolated from hospital wastewater (Nuñez \& Moretto, 2007) and some instances have been described that iodophors had been found to be contaminated with Pseudomonas sp (Anderson et al., 1984). However, there has been no report of $A$. hydrophila tolerant to PVPI so far.

This study confirmed the effect of organic matter on PVP-I sterilization and suggested that aquatic organic matter should be considered when PVP-I was used in aquaculture. The results showed the great bactericidal activities of the PVP-I in different aquaculture waters, and we recommended $25 \mathrm{ppm}$ for outdoor aquaculture and $20 \mathrm{ppm}$ for indoor treatment, which were safe and effective for normal swamp eel farming.

\section{Conclusions}

In conclusion, the organic matter in aquaculture water has negative influence on the bactericidal effectiveness of PVP-I. The minimum effective bactericidal concentration of PVP-I in indoor aquaculture water and outdoor aquaculture water was $10 \mathrm{ppm}$ and $20 \mathrm{ppm}$, respectively. 
The results suggest PVP-I could help prevent the transmission of $A$. hydrophila in swamp eel aquaculture.

\section{References}

Amend DF. 1974. Comparative Toxicity of Two Iodophors to Rainbow Trout Eggs. Transaction of the American Fisheries Society 103:73-78

Anderson RL, Berkelman RL, Mackel DC, Davis BJ, Holland BW, Martone WJ. 1984. Investigations into the survival of Pseudomonas aeruginosa in poloxamer-iodine. Applied and Environmental Microbiology 47:757762

Bergmann SM, Monro ES, Kempter J. 2017. Can water disinfection prevent the transmission of infectious koi herpesvirus to naive carp? - a case report. Journal of Fish Diseases 40: 885-893

Chang CT, Colicino EG, DiPaola EJ, Al-Hasnawi HJ, Whipps CM. 2015. Evaluating the effectiveness of common disinfectants at preventing the propagation of Mycobacterium spp. isolated from zebrafish. Comparative Biochemistry and Physiology, part C: 178, 45-50

Dukan S, Levi Y, Touati D. 1997. Recovery of culturability of an HOCl-stressed population of Escherichia coli after incubation in phosphate buffer: resuscitation or regrowth? Applied Environmental Microbiology 63: 4204-4209

Hershberger PK, Pacheco CA, Gregg JL. 2008. Inactivation of Ichthyophonus spores using sodium hypochlorite and polyvinyl pyrrolidone iodine. Journal of Fish Diseases 31: 853-858

Hossain MJ, Sun D, McGarey DJ, Wrenn S, Alexander LM, Martino ME, Xing Y, Terhune JS, Liles MR. 2014. An Asian origin of virulent Aeromonas hydrophila responsible for disease epidemics in United Statesfarmed catfish. mBio 5: e00848-00814

Jagoda SS, Wijewardana TG, Arulkanthan A, Igarashi Y, Tan E, Kinoshita S, Watabe S, Asakawa S. 2014. Characterization and antimicrobial susceptibility of motile aeromonads isolated from freshwater ornamental fish showing signs of septicaemia. Disease of Aquatic Organism 109: 127-137

Jahid IK, Ha SD. 2014. Inactivation kinetics of various chemical disinfectants on Aeromonas hydrophila planktonic cells and biofilms. Foodborne Pathogens and Disease 11:346-353 
325 Kersters I, Huys G, Van Duffel H, Vancanneyt M, Kersters K, Verstraete W. 1996. Survival potential of 326 Aeromonas hydrophila in freshwaters and nutrient-poor waters in comparison with other bacteria. The Journal 327 of Applied Bacteriology 80: 266-276

328 LeValley MJ. 1982. Acute toxicity of iodine to channel catfish (Ictalurus punctatus). Archives of 329 Environmental Health 29: 7-11

Lin CK. 2002. Toxicity of chlorine to different sizes of black tiger shrimp (Penaeus monodon) in low-salinity shrimp pond water. Aquaculture Research 33: 1129-1135

Lu X, Xiang Y, Yang G, Zhang L, Wang H, Zhong S. 2017. Transcriptomic characterization of zebrafish larvae in response to mercury exposure. Comparative Biochemistry and Physiology, part C 192: 40-49

Mainous ME, Smith SA, Kuhn DD. 2010. Effect of common aquaculture chemicals against Edwardsiella ictaluri and E. tarda. Journal of Aquatic Animal Health 22: 224-228

Nielsen ME, Hoi L, Schmidt AS, Qian D, Shimada T, Shen JY, Larsen JL. 2001. Is Aeromonas hydrophila the dominant motile Aeromonas species that causes disease outbreaks in aquaculture production in the Zhejiang Province of China? Disease of Aquatic Organism 46: 23-29

Nuñez L, Moretto J. 2007. Disinfectant-resistant bacteria in Buenos Aires City Hospital wastewater. Brazilian Journal of Microbiology 38:644-648

Oliver JD, Dagher M, Linden K. 2005. Induction of Escherichia coli and Salmonella typhimurium into the viable but nonculturable state following chlorination of wastewater. Journal of Water and Health 3: 249-257

Pianetti A, Manti A, Boi P, Citterio B, Sabatini L, Papa S, Rocchi MB, Bruscolini F. 2008. Determination of viability of Aeromonas hydrophila in increasing concentrations of sodium chloride at different temperatures by flow cytometry and plate count technique. International Journal of Food Microbiology 127:252-260

Rahman MH, Suzuki S, Kawai K. 2001. Formation of viable but non-culturable state (VBNC) of Aeromonas hydrophila and its virulence in goldfish, Carassius auratus. Microbiological Research 156: 103-106

Rodriguez Ferri, EF, Martinez S, Frandoloso R, Yubero S, Gutierrez Martin CB. 2010. Comparative efficacy of several disinfectants in suspension and carrier tests against Haemophilus parasuis serovars 1 and 5. Research in Veterinary Science 88: 385-389

Sanders ER. 2012. Aseptic laboratory techniques: plating methods. Journal of Visualized Experiments:e3064

Scarfe AD., Lee CS, O'Bryen PJ. 2006. Aquaculture Biosecurity. Blackwell Publishing 
353 Takeda A, Tsukada H, Takaku Y, Satta N, Baba M, Shibata T, Hasegawa H, Unno Y, Hisamatsu S. 2016. 354 Determination of Iodide, Iodate and Total Iodine in Natural Water Samples by HPLC with Amperometric and 355 Spectrophotometric Detection, and Off-line UV Irradiation. Analytical Sciences 32: 839-845

356 Truesdale VW, Luther GW. 1995. Molecular iodine reduction by natural and model organic substances in 357 seawater. Aquatic Geochemistry 1: 89-104

358 Truesdale VW, Luther GW, Canosa-Masb C. 1995. Molecular iodine reduction in seawater, an improved rate 359 equation considering organic compounds. Marine Chemistry 48:143-150

360 USFDA (U.S. Food and Drug Administration), 2010. Enforcement priorities for drug use in aquaculture. 361 Center for Veterinary Medicine, Program Policy and Procedures Manual Number, 1240.4200

362 Wang, CG, Li X, Yang SP, Li XY, Shi LL, Chen ZM, Sun CB. 2015. Study on the killing effect of six kinds of 363 disinfectants on bacteria in aquaculture seawater. Journal of Anhui Agricultural Sciences 43: 152-154

364 Wutzler P, Sauerbrei A, Klocking R, Burkhardt J, Schacke M, Thust R, Fleischer W, Reimer K. 2000. 365 Virucidal and chlamydicidal activities of eye drops with povidone-iodine liposome complex. Ophthalmic 366 Research 32: 118-125

367 Yoneyama A, Shimizu M, Tabata M, Yashiro J, Takata T, Hikida M. 2006. In vitro short-time killing activity 368 of povidone-iodine (Isodine ${ }^{\circledR}$ Gargle) in the presence of oral organic matter. Dermatology 212: 103-108 


\section{Figure 1}

Bactericidal efficacy of different povidone-iodine concentrations in four outdoor aquaculture water WA (A), WB (B), WC (C) and WD (D).

At each time point, the capital letters above the columns show extremely significant differences $(P<0.01)$; the little letters above the columns show significant differences $(P<0.05)$. The $y$-axis indicates the percent survival [percent survival $=(C F U$ of treatments/CFU of controls $) \times 100 \%$. Data are shown as means \pm SEM $(n=3)$.
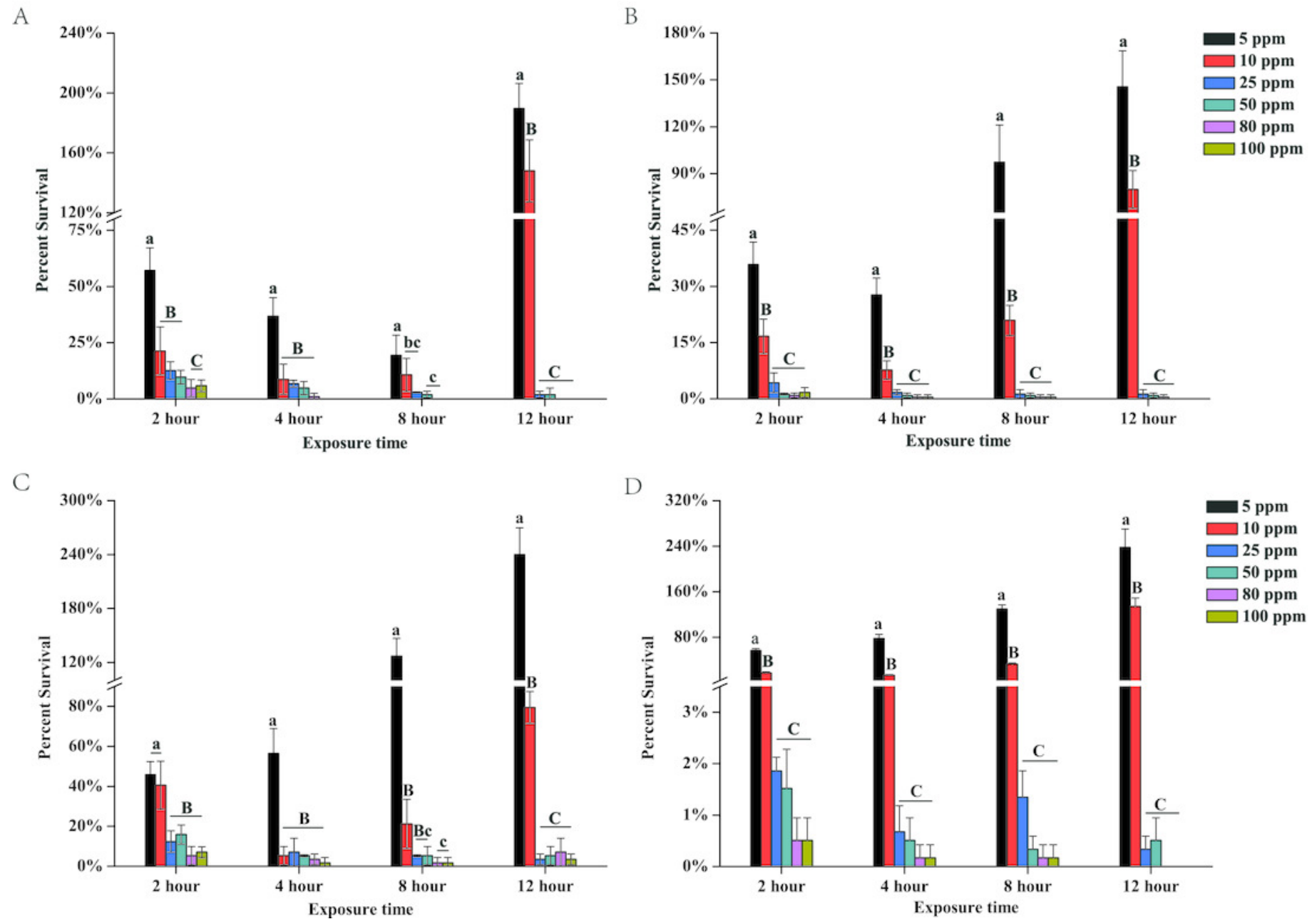
Figure 2

Bactericidal efficacy of povidone-iodine against six Aeromonas hydrophila isolates (Ah 1-6) in indoor aquaculture water (tap water).

The test bacterial concentration were $10^{3} \mathrm{CFU} / \mathrm{mL}(\mathrm{A}), 10^{4} \mathrm{CFU} / \mathrm{mL}(\mathrm{B})$ and $10^{5} \mathrm{CFU} / \mathrm{mL}(\mathrm{C})$. The $y$-axis indicates the percent survival. Data are shown as means \pm SEM $(n=3)$.

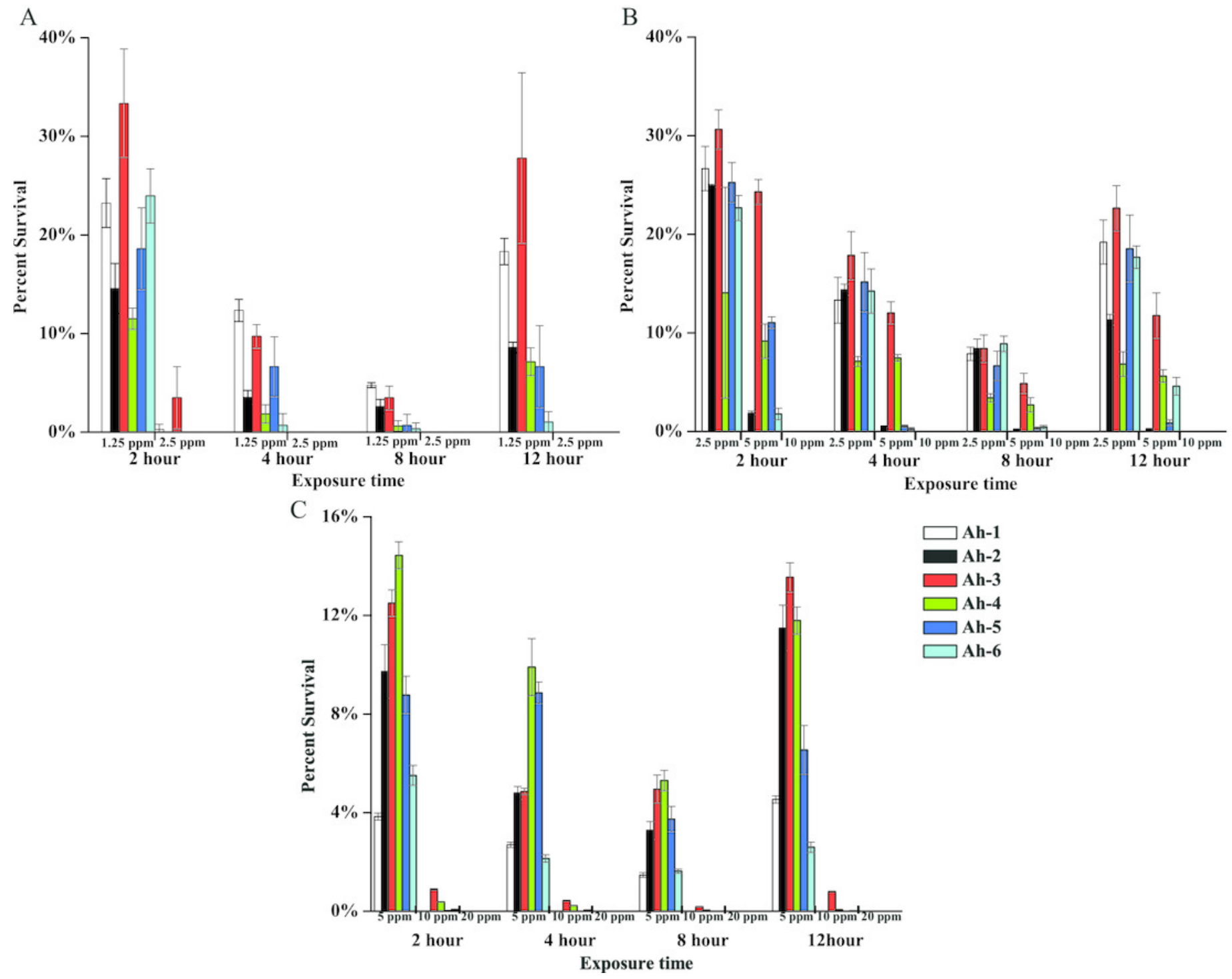




\section{Figure 3}

Bactericidal efficacy of povidone-iodine against Aeromonas hydrophila isolate (Ah 1 ) in Luria-Bertani broth. The tested bacterial concentration were $10^{3} \mathrm{CFU} / \mathrm{mL}(\mathrm{A}), 10^{4}$ $\mathrm{CFU} / \mathrm{mL}(\mathrm{B})$ and $10^{5} \mathrm{CFU} / \mathrm{mL}(\mathrm{C})$.

At each time point, the capital letters above the columns show extremely significant differences $(P<0.01)$, the little letters above the columns show significant differences $(P<0.05)$. The $y$-axis indicates the non-percent survival (non-percent survival $=C F U$ of treatments/CFU of controls). Data are shown as means \pm SEM $(n=3)$.

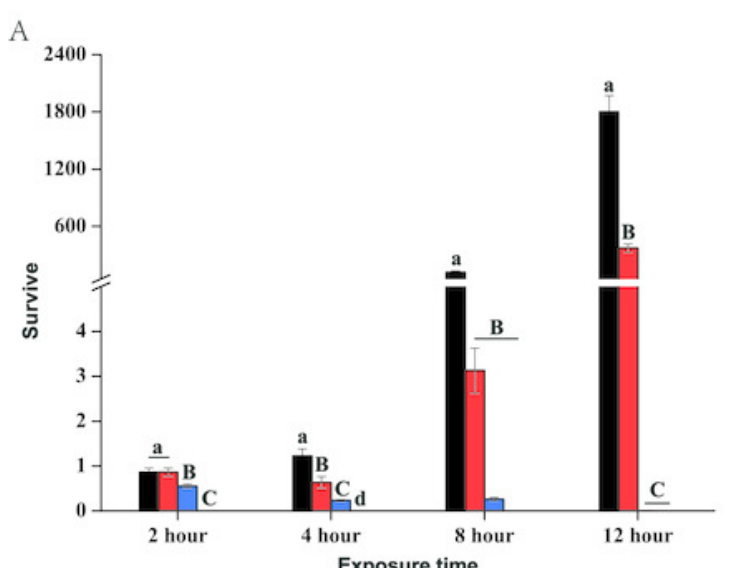

Exposure time

C
B

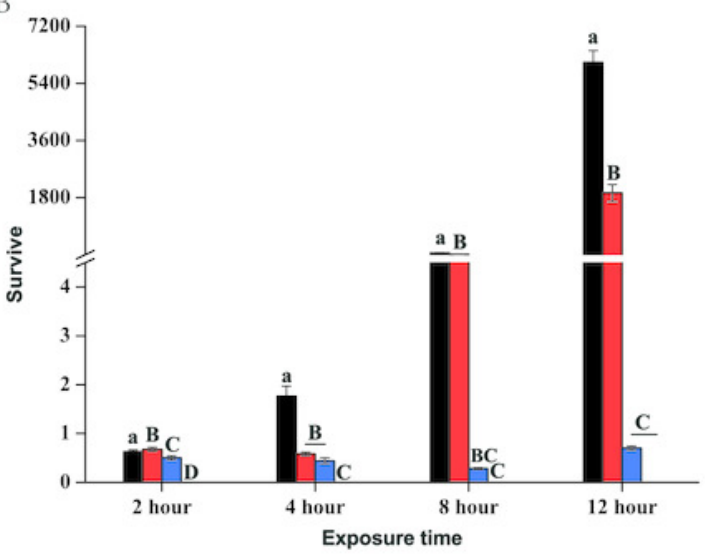

$500 \mathrm{ppm}$

$1000 \mathrm{ppm}$

$\square 2000 \mathrm{ppm}$

$\square 4000 \mathrm{ppm}$

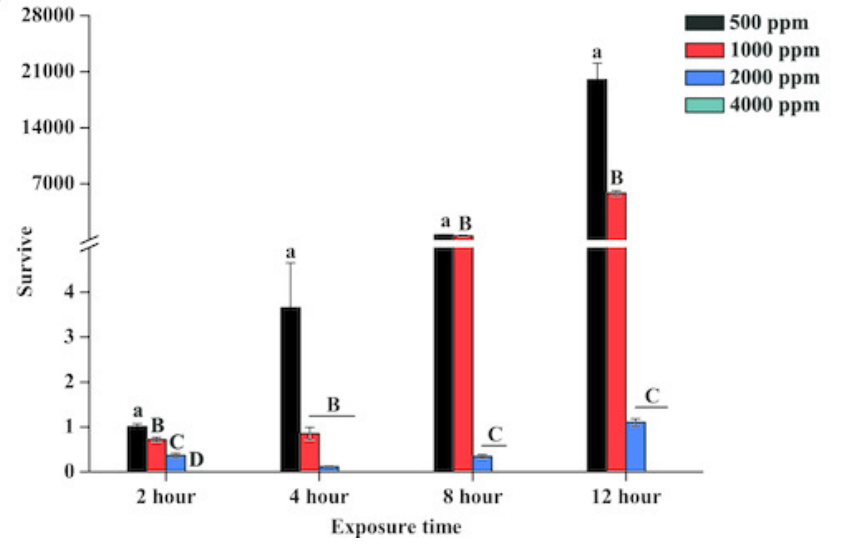


Figure 4

Effect of different LB concentrations on the effective iodine content of povidone-iodine.

Data are shown as means $\pm \operatorname{SEM}(n=3)$.

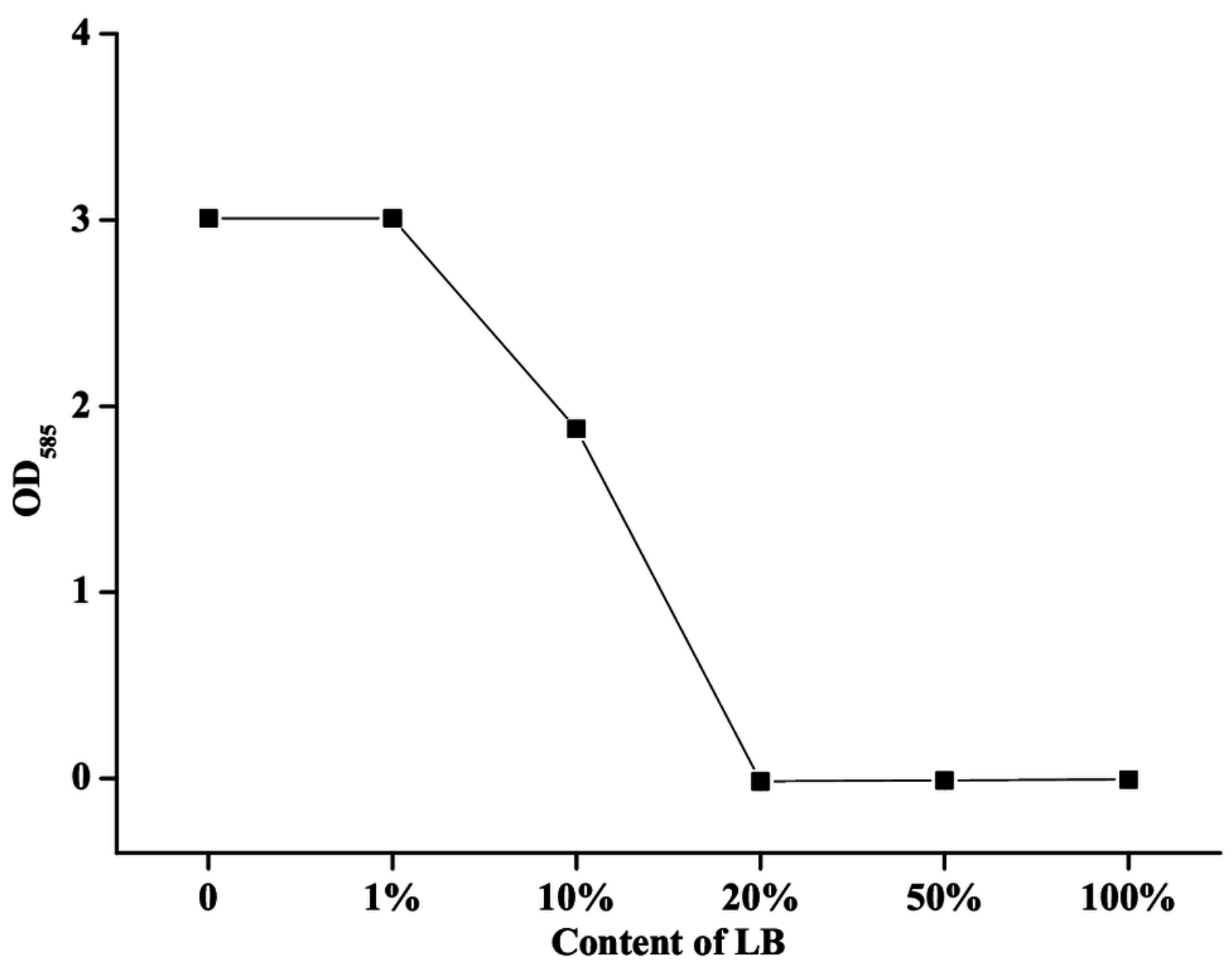

